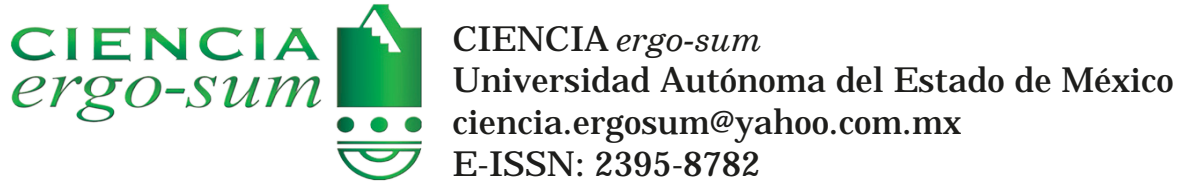

\title{
Evaluation of caries risk factors associated with pregnancy
}

\footnotetext{
Behnke Rivera, Karin Efride; González López, Blanca Silvia; Sánchez Vargas, Luis Octavio; Alanís Tavira, J orge; Bermeo Escalona, J osué Roberto

Evaluation of caries risk factors associated with pregnancy

CIENCIA ergo-sum, vol. 26, núm. 3, noviembre 2019-febrero 2020| e62

Universidad Autónoma del Estado de México, México

Esta obra está bajo una Licencia Creative Commons Atribución-NoComercial-SinDerivar 4.0 Internacional.
}

Behnke Rivera, K. E., González López, B. S., Sánchez Vargas, L. O., Alanís Tavira, J . y Bermeo Escalona, J . R. (2019). Evaluation of caries risk factors associated with pregnancy. CIE NCIA ergo-sum, 26(3). 


\title{
Evaluation of caries risk factors associated with pregnancy
}

Evaluación de los factores de riesgo a caries asociados con el embarazo

\author{
Karin Efride Behnke Rivera \\ Universidad Autónoma del Estado de México, México \\ karinbehnke@hotmail.com \\ Blanca Silvia González López \\ Universidad Autónoma del Estado de México, México \\ gblancasilvia@yahoo.com \\ Luis Octavio Sánchez Vargas \\ Universidad Autónoma de San Luis, México \\ lo.sanchezvargas@gmail.com \\ Jorge Alanis Tavira \\ Universidad Autónoma del Estado de México, México \\ jalanist@uaemex.mx \\ Josué Roberto Bermeo Escalona \\ Universidad de la Salle Bajío, México \\ josuer84@hotmail.com
}

Recepción: 06 de diciembre de 2017

Aprobación: 30 de mayo de 2018

\begin{abstract}
Tooth decay in pregnant women is frequent; the Cariogram is a useful tool for the identification of risk factors for dental caries. The aim is to determine risk to dental caries in pregnant women. A convenience sample of 55 healthy women between 18 and 40 years old in their last trimester of pregnancy, recruited from public hospitals of the State of Mexico, were studied. According to Cariogram factors $58 \%$ of patients can develop new carious lesions, due to their diet and presence of cariogenic bacteria (20\%), susceptibility (11\%) and circumstances (7\%). The Cariogram is an efficient tool to identify caries risk factors in pregnant women. A correlation was observed between the identified factors and the Decayed Missing, Filled, Teeth surfaces Index (DMFT).
\end{abstract}

KEYWORDS: Cariogram, Caries risk, pregnancy.

\section{RESUMEN}

Debido a que la caries dental es un problema común en mujeres embarazadas, el propósito es determinar el riesgo de padecerla en una muestra por conveniencia de 55 mujeres sanas en su último trimestre de embarazo, de entre 18 y 40 años de edad provenientes de hospitales públicos del Estado de México. Según los factores del cariograma, 58\% de las pacientes puede desarrollar nuevas lesiones cariosas debido a su dieta y a la presencia de bacterias cariogénicas (20\%), susceptibilidad (11\%) y circunstancias (7\%). Los resultados muestran que el cariograma es una herramienta útil para identificar factores de riesgo a la caries en mujeres embarazadas. Se observó una correlación entre los factores identificados y el índice de dientes cariados, perdidos y obturados (CPOD).

PALABRAS ClAVE: cariograma, riesgo a caries, embarazo.

\section{INTRODUCTION}

Tooth caries is a common infectious disease related to the interaction of biological, behavioral and socio-economic factors (Çolak et al., 2013). 
Pregnancy represents a particular physiological state, characterized by hormonal and metabolic changes. Despite the increase of carious lesions, their severity in pregnant women has not been demonstrated (Wagle et al., 2018). It is believed, that pregnancy could increase the risk of caries initiation or progression by changes in saliva composition, gastric reflux, or deficient oral health care (Villa et al., 2013; Oviedo et al., 2011).

There are several models of risk estimation (Reis et al., 2010; Nisar, 2015, Featherstone et al., 2007; Kaur et al., 2013), but one of the most used is the Cariogram of Brattall and Hänsel Peterson (Gómez Clavel, \& Peña Castillo, 2014). It has been used to identify caries risk in focused groups (Merdad et al., 2010; Bratthall, \& Hänsel Petersson, 2005; Piovano et al., 2010), for clinical or health promotion purposes. Although there are no risk caries reports using the Cariogram; risk factors associated with the development of new decay in teeth and progression of pre-existing caries have been described (Gaffield et al., 2001) this model is also used to analyze dental treatment needs (Gupta et al., 2015).

The Cariogram evaluates caries experience, related systemic diseases, and diet content, diet frequency, and plaque index, levels of Streptococcus mutans, fluoride program, salivary secretion, salivary $\mathrm{pH}$ and clinical judgment, according to its built-in algorithm. The program evaluates the data and presents the summarized results as a pie chart, illustrating the chance of avoiding cavities (González Martínez et al., 2009), with the purpose of encouraging preventive measures before new cavities could develop (Bratthall et al., 2004).

To our knowledge, there are no previous studies yet that have reported the frequency of tooth decay and caries risk factors among pregnant women in the State of Mexico. Knowledge of the prevalence of tooth decay and associated risk indicators during pregnancy would help to develop educational and preventive actions (De Aguiar et al., 2011), and reduce complications during pregnancy (Naseem et al., 2016). Besides, the reduction of Streptococcus mutans levels in the mother's saliva could prevent or retard their establishment in the children's mouths (Meyer et al., 2010; Rojas, \& Echeverrría, 2014).

The purpose of this study is to assess risk factors associated with dental caries in pregnant woman.

\section{Materials and methods}

A cross-sectional study was conducted in a convenience sample of 55 patients; recruited at public Hospital of Mother and Child care, Hospital Materno Perinatal "Mónica Pretelini Sáenz" and the Maternal and Child Institute of the State of Mexico (Instituto Materno Infantil del Estado de México), previous authorization of the ethics committees and directors of the hospitals. Patients were informed of the research and voluntarily participated and signed the informed consent. The inclusion criteria were: healthy pregnant women in the last gestation trimester, from 18 to 40 years old, free of active caries (because teeth with open cavities are considered a reservoir for installation, incubation and propagation of bacteria). Exclusion criteria were: patients receiving medical treatment and with systemic disease and high-risk pregnancies.

The protocol was reviewed and accepted by the Ethics Committee of Medical Sciences Center at Autonomous University of the State of México.

Data were collected as follows:

1) Caries experience: A trained and calibrated examiner obtained DMFT index by clinical examination of each patient.

2) Related systemic diseases: The information was obtained by face-to-face interviews and registered in medical records.

3) Diet content: A colony count of salivary lactobacilli was performed with the CRT Bacteria Ivoclar Kit. Patients were asked to chew a paraffin and the stimulated saliva was deposited in a sterile container, and then $1 \mathrm{ml}$ of this saliva was taken and planted in the Rogosa agar palette for lactobacilli identification. Then, the samples were incubated 48 hours. The results were classified according to the manufacturer's 
scale (low, medium and high), depending on the number of bacterial colonies found in the agar. This test estimated the cariogenic diet and fermentable carbohydrates.

4) Diet frequency: The number of meals taken in a day using a 24-hour diet remainder was registered.

5) Plate index: Oral hygiene assessment was obtained using the index plate Silness- Löe.

6) Streptococcus mutans: The bacterial amount was obtained with the CRT Bacteria Ivoclar Kit, by placing stimulated saliva in the Mitis salivarius agar palette and incubated for 48 hours. Palettes were classified as low, medium or high colonies of Streptococcus mutans, according to the table provided by the manufacturer.

7) Fluoride program: The exposure to fluorides contained in toothpastes, rinses and professional fluoridation programs, was determined by face-to-face interviews and included in the clinical history.

8) Salivary secretion: This was performed by salivary stimulation with a paraffin pellet. The patients were asked to chew a bar of paraffin for 3 minutes and the saliva was deposited into a sterile container. The amount of collected saliva was then measured using sterile pipettes.

9) Salivary $\mathrm{pH}$ : Fermented $\mathrm{pH}$ test strips were soaked in saliva for 3 minutes, and the resulting color on the test strip was compared against the scale provided by the manufacturer.

10) Clinical examination: The examiner's assessment was rated upon clinical examination and the results of the criteria previously described were considered.

The obtained data were recoded according to a predetermined scale, which were entered in the Cariogram software. The program then generated a pie chart where color red represents bacteria, purple means diet, light blue signifies susceptibility, yellow denotes circumstances, and green exemplifies the chance to avoid caries.

The clinical examinations were performed at the School of Odontology of the Autonomous University of the State of Mexico during 2014-2015. The examinations were performed by one dentist. The examiner was calibrated regarding the diagnostic criteria through practice and through discussing cases before the clinical examinations. All patients were examined and recorded by using standard protection barriers, decayed, missing and filled teeth (DMFT), aided by a mirror. Descriptive analysis of the sample was performed using percentages obtained from the Cariogram and were analyzed in the SPSS 19 vs the program. A Spearman's test, $p \leq 0.05$, was also performed to identify the Cariogram variables that correlated with the DMFT index.

\section{Results}

Participant pregnant women were 18 to 40 years old, mean $29.05 \pm 6.7$ years.

The analyzed data in the Cariogram show that $42 \%$ of patients have the chance to avoid new carious lesions; the overall caries risk of the patients is high at $58 \%$, and those who have the probability to develop new lesions, due to diet and bacteria (20\%), susceptibility (11\%) and circumstances (7\%) (Figure 1).

About two-thirds of the women have high and moderate fermentable carbohydrate intake and its frequency of consumption was between a maximum of five meals and more than seven meals per day.

Considering the plaque amount, $33 \%$ of the patients show both less than good oral hygiene and poor oral hygiene; and this explained the high and very high levels of Streptococcus mutans detected.

Almost all patients have received fluoride toothpaste as the only contact with this preventive measure.

The caries experience risk factor from the Cariogram showed that $36.36 \%$ of the women had higher dental caries experience than expected in this age group. None of the patients reported general diseases related to the risk of developing dental caries.

Through clinical examination, it was observed that $19 \%$ of the women in the study were in better condition than the diagnosis obtained by the Cariogram; $36.36 \%$ of the cases were similar to those described in the Cariogram; whereas $29.09 \%$ of patients were qualified in a clinical state worse than what the Cariogram displayed; and $14.54 \%$ of patients were classified as very high risk. 


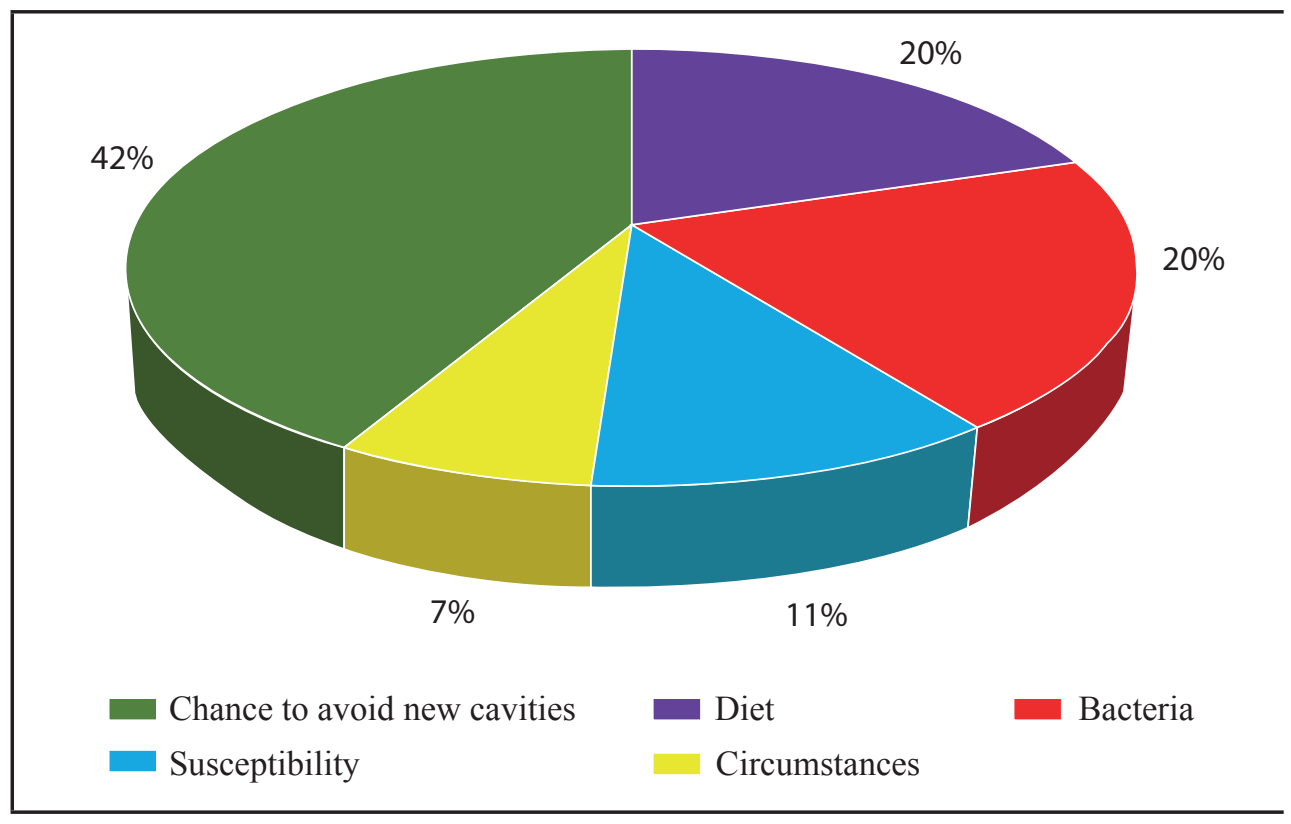

FIGURE 1

General Cariogram

Source: Own elaboration.

The summarized results of the sectors obtained by the graph of the Cariogram are shown in Table 1 .

Caries experience, plaque amount, diet frequency, level of Streptococcus mutans and clinical judgment displayed by the Cariogram and recoded to correlation analysis were the variables significantly correlated with the DMFT (Table 2).

\section{Discussion}

From 95 women only 55 pregnant women were included in the study; the rest did not meet the inclusion criteria or did not agree to participate in the study, several of them with inequality and social backwardness. They were selected, considering that, they were in the third trimester of pregnancy, and because once they were identified the risk factors, they were incorporated into a prevention and health promotion program that included their babies up to six months of age (Data not shown).

Carious lesion is the most common dental disease, and pregnancy represents a particular state of physical, hormonal and metabolic change that can produce an imbalance in oral cavity (Silk et al., 2008). We have found a direct relationship between DMFT and plaque amount, diet frequency, level of Streptococcus mutans, caries experience and clinical judgment in pregnant women. Through the clinical judgment, a low percentage of the patients showed low risk to develop new caries lesions. However, the Cariogram analysis allows to correctly diagnosing the risk of caries in these patients, as analyzed by the Cariogram in addition to the study of clinical judgment, diet, oral hygiene, bacteria and DMFT (Bratthall, \& Hänsel Petersson, 2005).

In our study, most of the patients showed less plaque amount than what was expected in the same age group, though high levels of Streptococcus mutans were observed. Nevertheless, there was no correlation between plaque amount and levels of Streptococcus mutans. This finding could be due to the samples that were taken from saliva, and evaluated by the CRT Bacteria Ivoclar Kit, which is a specific system of detection of Streptococcus mutans independent of the plaque amount.

It is possible that the high levels of bacteria could be due to diet, hormonal changes, or acidic salivary $\mathrm{pH}$; it is well known that these factors contribute to the colonization of the mouth (Núñez, \& García Bacallao, 2010). 
TABLE 1

Score distribution of factors obtained by the Cariogram

\begin{tabular}{|c|c|c|c|}
\hline $\begin{array}{l}\text { Cariogram Factor } \\
\text { Sector of the graph }\end{array}$ & Risk Factor & & $\begin{array}{c}\text { Percentage } \\
\%\end{array}$ \\
\hline \multirow{4}{*}{$\begin{array}{l}\text { Circumstances } \\
\text { (low) }\end{array}$} & \multirow{4}{*}{ Caries experience } & Circumstances (yellow) & 49.09 \\
\hline & & Better than normal that age group & 9.09 \\
\hline & & Normal for age group & 5.45 \\
\hline & & Worse than normal for that age group & 36.36 \\
\hline \multirow{8}{*}{ Diet (dark blue) } & \multirow{4}{*}{ Diet, contents } & Very low fermentable carbohydrate & 12.72 \\
\hline & & Low fermentable carbohydrate & 18.18 \\
\hline & & Moderate fermentable carbohydrate & 32.72 \\
\hline & & High fermentable carbohydrate & 36.36 \\
\hline & \multirow{4}{*}{$\begin{array}{l}\text { Diet, frequency } \\
\text { (dark blue) }\end{array}$} & Maximum of three meals per day (including snacks) & 3.63 \\
\hline & & Maximum of five meals per day & 60 \\
\hline & & Maximum of seven meals per day & 21.81 \\
\hline & & More than seven meals per day & 14.54 \\
\hline \multirow{7}{*}{ Bacteria (red) } & \multirow{4}{*}{$\begin{array}{l}\text { Plaque amount } \\
\text { (red) }\end{array}$} & Extremely good oral hygiene & 56.36 \\
\hline & & Good oral hygiene & 10.9 \\
\hline & & Less than good oral hygiene & 9.09 \\
\hline & & Poor oral hygiene & 23.63 \\
\hline & \multirow{3}{*}{$\begin{array}{l}\text { Streptococcus mutans } \\
\text { (red) }\end{array}$} & Low levels of Streptococcus mutans in saliva & 7.27 \\
\hline & & High amount of Streptococcus mutans in saliva & 29.09 \\
\hline & & Very high amounts of Streptococcus mutans in the saliva & 63.63 \\
\hline \multirow{6}{*}{$\begin{array}{l}\text { Susceptibility } \\
\text { (blue) }\end{array}$} & \multirow{2}{*}{$\begin{array}{l}\text { Fluoride program } \\
\text { (light blue) }\end{array}$} & Fluoride toothpaste only & 96.36 \\
\hline & & Avoiding fluorides, no fluoride & 3.63 \\
\hline & \multirow{3}{*}{$\begin{array}{l}\text { Saliva buffer capacity } \\
\text { (light blue) }\end{array}$} & $\mathrm{pH}>6.0$ & 96.36 \\
\hline & & $\mathrm{pH} 4.5-5.5$ & 1.81 \\
\hline & & $\mathrm{pH}<4.0$ & 1.81 \\
\hline & $\begin{array}{l}\text { Saliva secretion - } \\
\text { amount (light blue) }\end{array}$ & $>0.7 \mathrm{ml} / \mathrm{min}$ & 100 \\
\hline \multirow{3}{*}{ Clinical judgment } & \multirow{3}{*}{ Very high caries risk } & Normal setting; risk according to the other values entered & 36.36 \\
\hline & & $\begin{array}{l}\text { Worse than what the Cariogram showed based on the } \\
\text { scores entered }\end{array}$ & 29.09 \\
\hline & & Very high caries risk & 14.54 \\
\hline
\end{tabular}

TABLE 2

Variables of the Cariogram that are significantly correlated with the DMFT

\begin{tabular}{|lcc}
\hline \multicolumn{1}{c}{ Variable } & Rho & $\mathrm{P}$ \\
\hline Caries experience & 0.478 & $<0.01$ \\
Diet, frequency & 0.237 & $<0.04$ \\
Streptococcus mutans & 0.274 & $<0.02$ \\
Plaque, amount & 0.295 & $<0.01$ \\
Clinical judgment & 0.338 & $<0.00$ \\
\hline
\end{tabular}

Source: Own elaboration. 
According to the Cariogram, almost half of the participating women have the chance of avoiding new lesions; however, as the experience of tooth decay was one of the main risk factors for caries detected, previous caries increased in these women with the possibility of developing new lesions. In addition, caries experience, could increase level and pathogenicity of Streptococcus mutans because the antecedent of bacterial presence, it has been established that previous experience of decay is the most accurate predictor of caries risk (Gutiérrez-Salazar et al., 2008; Hänsel Petersson, \& Twetman, 2015; Gamboa, \& Cortés, 2013).

The correlation analysis disclosed that bacteria and diet are the most important risk factors to tooth decay in pregnant women included in this study. The Streptococcus mutans count in the examined women was higher than $100000 \mathrm{cfu} / \mathrm{ml}$ of saliva. The oral colonization by Streptococcus mutans is required for dental caries initiation and it has been suggested that a Streptococcus mutans amount higher than $105000 \mathrm{cfu} / \mathrm{ml}$ of saliva is related to higher caries risk (Petti, \& Hausen, 2000). According to De Souza et al. (2015), Streptococcus mutans is the main cause of tooth decay in pregnant women.

We found that the Streptococcus mutans levels and the plaque amount in one-third of the participating women were high, due to deficient oral hygiene, and a rich fermentable diet; however, women with good hygiene also show high levels of Streptococcus mutans. Molnar-Varlam et al. (2011) reported that as pregnancy progresses, Streptococcus mutans levels rise mainly from the second trimester of pregnancy, the presence of plaque also increases; deficient oral hygiene also increases with the frequency and intake of fermentable carbohydrates (Molnar-Varlam et al., 2011; Peker et al., 2012). These features were similar to those detected in our patients. Additionally, it had been suggested that deficient oral hygiene in pregnant women is a condition of high risk than the intake of sugary foods (Rodríguez Lezcano et al., 2013).

In addition to the aforementioned risk factors, it is widely known the fact that diseases either by deficit in salivary secretion due to drugs or the disease itself (Ehremberg et al., 2015), predispose the development of caries. With the purpose of controlling the variable none of the patients included in the study, presented systemic diseases related with predisposition to developing caries.

Majority of the pregnant women reported the use of fluoride toothpaste as the only contact with fluoride preventive measure. Fluoride, along with calcium, phosphorus and magnesium, protects the dental and bone structures of the mother and future offspring (Kloetzel et al., 2011).

Most toothpastes and mouthwashes contain fluoride, a proven anticaries, which strengthens the tooth enamel and makes it more resistant to the acids generated by plaque; also, applications of topical fluoride presentations, giving good results (Maturo et al., 2011). Pregnant women in this study had lower (6.0) salivary $\mathrm{pH}$ than the usual salivary $\mathrm{pH}$, but salivary flow rate was found between normal ranks (Maturo et al., 2011). Salivary $\mathrm{pH}$ during pregnancy may increase its acidity due to exposure to gastric juices, hyperemesis and gastric reflux (Silk et al., 2008). The flow rate of saliva of the patients was normal as it was expected because while the level of estrogen is high, the saliva flow is retained at normal levels (Martínez-Pabón et al., 2014). Risk predictor models such as the Cariogram aid clinicians in detecting risk caries factors are easy to show them to the patients; however, clinical judgment cannot be replaced, as we found that the risk was not similar to the results of the Cariogram. In approximately half of the cases, the risk was either better or worse than what the Cariogram risk displayed.

The Cariogram is a useful tool to determine the caries risk in epidemiological studies and provides information about implementing preventive procedures (Gonzalez, \& Okunseri, 2010).

Moreover, the bacterial count is an important risk factor; however, as we reported, it is not a unique and determinant factor. It was demonstrated that the reduced Cariogram model could be useful to study individual patients (Gómez Clavel, \& Peña Castillo, 2014) and populations (Peker et al., 2012), in such cases, the patient's honesty is necessary to get accurate data. Therefore, it is of value to promote the use of the reduced Cariogram model in public health services where pregnant women are to be examined, and when culture media are not an affordable option. 
Although the risk to decay varies across patients, as we have seen in this study, patients should be monitored routinely (Better Health Channel, 2018). At present, there is no system with satisfactory validity for the assessment of risk caries. However, Cariogram is a useful tool that identifies the most important risk factors individually and in groups of high-risk populations, with the advantage of enabling the patient to recognize the risk factors and motivate them in their participation on available preventive measures (Tellez et al., 2014).

Caries risk assessment is fundamental to preventing and controlling the disease, to identifying factors that influence carious activity, to aiding towards guiding preventive actions for those who are at high caries risk, including pregnant women (Bratthall et al., 2004).

There are risk models used to recognize multiple causative caries factors or used to predict caries development in the future, and such models are useful to evaluate caries risk assessment in various populations (Bratthall, \& Hänsel Petersson, 2005).

The Cariogram is a computer program that allows individual risk assessment and implementation of an individual prevention program. It has also been successful in assessing caries risk in specific groups of population (Hebbal et al., 2012). This tool also permits risk calculation by analyses of the input data including caries experience, related diseases, diet contents and frequency, plaque amount, Streptococcus mutans count, fluoride program, saliva secretion and buffer capacity (Celik et al., 2012). Further, this program, shown as a pie chart, is able to identify opportunities to avoid new carious lesions, and the probability of each of its variables that influences developing new lesions (Bratthall, \& Hänsel Petersson, 2005).

This information allows clinicians to suggest preventive measures to avoid the development of new caries (Celik et al., 2012).

Given the advantages of the software and the pie-chart presentation that can help motivate patients, the risk factors of caries in pregnant women were evaluated through the Cariogram.

The Cariogram can be a very useful tool for the monitoring and motivation of dental patients. It has been widely used in children and adolescents and even in the elderly, its use in pregnant women is not widespread, although in this study, the sample is small, the results are encouraging, it would be convenient to apply the study to a representative population, early from the first months of pregnancy attending public and private gynecologist services. In addition, it could be recommendable to promote multidisciplinary prevention and promotion campaigns for health, including gynecologist care and the use of reduced Cariogram in pregnant women in rural communities and with lack of dental medical services. According, to the National Institute of Statistic and Geography (INEGI, Instituto Nacional de Estadística y Geografía, 2017), in the State of Mexico thought 19\% of women are no affiliated to public health services; $87 \%$ have prenatal consultations and $87.4 \%$ consultations in the first three months of pregnancy, it means that they could be sensitive to the recommendations of promotion and prevention for their health and the health of their babies.

\section{Conchusion}

The risk factors associated with dental decay in pregnant women were caries experience, plaque amount, diet frequency, and level of Streptococcus mutans. The Cariogram is an efficient tool to identify caries risk factors in pregnant women, as also confirmed by the results of our correlation analysis of the risk factors detected by the software and DMFT.

\section{Prospective}

Dental caries is an infectious disease that affects population of all age groups (Çolak et al., 2013). The disease begins at an early age related to the acquisition of bacteria absolutely identified as responsible for the development of caries and encouraged by poor eating habits (Güler, \& Köprülü, 2011). 
The natural history of the disease allows the implementation of actions at all levels of prevention and care, resulting preventive measures before disease is established and even in the initial stages, the most economical and easy action to implement (De Aguiar et al., 2011).

Once the disease is established, it is possible to repair the damage; in these cases, the cost of care is variable depending on the number of teeth with caries and the degree of affectation at the time of diagnosis.

For that reason, the participation of qualified personnel, infrastructure and specialized materials are necessary, (Medina Solís. et al., 2006). To avoid limiting access to these services to patients in rural areas which nonexistence of dental medical services, also to patients with low economic resources (Fernandez-Barrera et al., 2016).

Unfortunately, most patients seek care when they have severe pain or even complications as dissemination of the disease to the tissues of the stomatognathic apparatus. In these cases, patients choose extraction of the teeth because they cannot endorse an endodontic treatment or because the state of the dental organ no longer allows another treatment option. Therefore, a high percentage of the adult and older adult population is partially or fully edentulous, which causes malnutrition, phonetic and aesthetic problems (Vargas et al., 2001).

Prevention programs such as the application of fluoride, fluoridated salt, health promotion activities are mainly targeted at school-age children, also actions in pregnant woman have been implemented, however the incidence and prevalence of caries in these groups have not been substantially reduced (Reis et al., 2010).

In our state, country and even around the world early dental caries of childhood has become a problem of public health, with great economic and social implications (WHO Expert Consultation on Public Health Intervention against Early Childhood Caries, 2016). It has been postulated that mothers play a definitive role in the transmissibility of caries to their children (Da Silva bastos et al., 2015), even since the birth, reduction of Streptococcus mutans levels in mothers' saliva could prevent or retard bacterial establishment in children's mouths (Volpato et al., 2011). The best time for the implementation of preventive measures to avoid the development of early caries seems to be during pregnancy, since the mother is particularly motivated for the care of the baby.

The Cariogram is a useful tool that can identify those most important risk factors, individually and in groups of population of high-risk, with the great advantage of enabling the patient to recognize the risk factors and motivate their participation in preventive available measures (Bratthall et al., 2004).

An appropriate treatment in pregnant women based on individual risk factors will support health promotion and education activities and the opportunity for a dental health in the baby and throughout his life.

\section{ReFERENCES}

Bratthall, D., Hänsel Petersson, G., \& Stjernswärd, J. R. (2004). Cariogram Manual. Internet Version 2.01.

Bratthall, D., \& Hänsel Petersson, G. (2005). Cariogram--a multifactorial risk assessment model for a multifactorial disease. Community Dentistry and Oral Epidemiology, 33(4), 256-64.

Better Health Channel. (2018) Caries concerns in ante and post natal care. Retrevied from: https://www.betterhealth.vic.gov.au/health/healthyliving/pregnancy-and-teeth?viewAsPdf=true

Celik, E. U., Gokay, N., \& Ates, M. (2012). Efficiency of caries risk assessment in young adults using Cariogram. European Journal of Dentistry, 6(3), 270-279.

Çolak, H., Dülgergil, T., Dalli, M., \& Hamidi Mustafa, M. (2013). Early childhood caries update: A review of causes, diagnoses, and treatments. Journal of Natural Science, Biology, and Medicine, 4(1), 29-38.

Da Silva Bastos, V. de A., Freitas-Fernandes, L. B., Fidalgoa, T. K., Martins, C., Mattos, C.T., De Souzaa, I. P. \&, Maia L. C. (2015). Mother-to-child transmission of Streptococcus mutans: A systematic review and meta-analysis. Journal of Dentistry, 43(2), 181-191 
De Aguiar, T. C., Valsecki Junior, A., Rocha Corrêa, S., Lopez Rosell, F., \& Pereira, E. (2011). Avaliação do perfil de risco de cárie dentária em gestantes de Araraquara, Brasil. Revista Cubana de Estomatología, 48(4), 341-351.

De Souza, P. M., Mello Proença, M. A., Franco, M. M., Rodrigues, V. P., Costa, J. F., \& Costa, E. L. (2015). Association between early childhood caries and maternal caries status: A cross-section study in São Luís, Maranhão, Brazil. European Journal of Dentistry, 9(1), 122-126.

Ehremberg, N., Morales, D., Hempel, C., Salgado, C., Faleiros, S., \& Rodríguez, G. (2015). Asociación entre las variables del Cariograma e historia de caries en la población de 15 a 64 años de la comuna de Tortel, provincia del Capitán Prat de la XI Región de Aysén, Chile: análisis multivariable. Revista de Periodoncia, Implantología y Rehabilitación Oral, 8(1), 7-16.

Featherstone, J., Domejean- Orleaguet, S., Jenson, L., Wolff, M., \& Young, A. (2007). Caries risk assessment in practice for age 6 through adult. Journal of the California Dental Association, 35(10), 703-713.

Fernandez-Barrera, M. Á., Medina-Solís, C.E., Vera-Guzmán, S., Ascencio-Villagrán, A., Minaya-Sánchez, M., Casanova-Rosado, A. J. (2016). Edentulismo en adultos de Pachuca, México: aspectos sociodemográficos y socioeconómicos. Revista Clínica de Periodoncia, Implantología y Rehabilitación Oral, 9(1), 59-65.

Gaffield, M., Gilbert, B., Malvitz, D., \& Romaguera, R. (2001). Oral health during pregnancy. Journal of the American Dental Association, 132(7), 1009.

Gamboa, L. F., \& Cortés, A. (2013). Valoración del riesgo de caries: ¿̇mito o realidad? Universitas Odontológica, 32(68), 69-79.

Gómez Clavel, J. F., \& Peña Castillo, R. E. (2014). Risk assessment associated with caries. Revista ADM, 71(2), 58-64.

Gonzalez, C. D., \& Okunseri, C. (2010). Senior dental students' experience with cariogram in a pediatric dentistry clinic. Journal of Dental Education, 74(2), 123-9.

González Martínez, F., Sánchez Pedraza, R., \& Carmona Arango, L. (2009). Risk indicators for dental caries in preschool children from La Boquilla. Revista de Salud Pública, 11(4), 620-630

Gupta, D., Momin, K. R., Mathur, A., Srinivas, K. T., Jain, A., Dommaraju, N., Dalai, R. D., \& Gupta, K. R. (2015). Dental caries and their treatment needs in 3-5 year old preschool children in a Rural District of India. North American Journal of American Sciences, 7(4), 143-150.

Gutiérrez-Salazar, P., Morales-Ramírez, J. J., \& Jiménez García, G. A. (2008). La experiencia previa de caries en la predicción de riesgo: aspectos metodológicos. Boletín Médico del Hospital Infantil de México, 65(8), 341-352.

Güler E, Köprülü H. (2011). Preventive measures to reduce the transfer of Streptococcus mutans from pregnant women to their babies. Journal of Dental Sciences, 6(1), 14-18.

Hänsel Petersson, G., \& Twetman, S. (2015). Caries risk assessment in young adults: a 3 year validation of the Cariogram model. BMC Oral Health, 15(1), 15-17.

Hebbal . M., Ankola, A., \& Metgud, S. (2012). Caries risk profile of 12 year old school children in an Indian city using Cariogram. Medicina Oral, Patología Oral y Cirugía Bucal, 17(6), 1054-61.

INEGI (Instituto Nacional de Estadística y Geografía). (2017). Mujeres y hombres 2017. Retrevied from http:// cedoc.inmujeres.gob.mx/documentos_.

Kaur, A., Kwatra, K. S, \& Kamboj, P. (2013). Evaluation of non-microbial salivary caries activity parameters and salivary biochemical indicators in predicting dental caries. Journal of Indian Society of Pedodontics and Preventive Dentistry, 30(3), 212-217.

Kloetzel, M. K, Huebner, C. E., \& Milgrom, P. (2011). Referrals for dental care during pregnancy. Journal of Midwifery Women's Health, 56(2), 110-117. 
Martínez-Pabón, C. M., Martínez-Delgado, C. M., López-Palacio, A. M., Patiño-Gómez, L. M., Arango-Pérez, E.A. (2014). Características fisicoquímicas y microbiológicas de la saliva durante y después del embarazo. Revista de Salud Pública, 16(1) 128-138.

Maturo, P., Costacurta, M., Perugia, C., \& Docimo, R. (2011). Fluoride supplements in pregnancy, effectiveness in the prevention of dental caries in a group of children. Oral \& Implantology, 4(1-2), 23-27.

Medina-Solís, C. E., Maupome, G., Avila-Burgos, L., Pérez-Nuñez, R., Pelcastre-Villafuerte, B., \& Pontigo-Loyola A. P. (2006). Políticas de salud bucal en México: disminuir las principales enfermedades.Una descripción. Revista Biomédica, 17, 269-286.

Merdad, K., Sonbul, H., Gholman, M., Reit, C., \& Birkhed, D. (2010). See comment in PubMed Commons below Evaluation of the caries profile and caries risk in adults with endodontically treated teeth. Oral Surgery, Oral Medicine, Oral Pathology, and Oral Radiology, 110(2), 264-269.

Meyer, K., Geurtsen, W., \& Günay, H. (2010). An early oral health care program starting during pregnancy Results of a prospective clinical long-term study. Clinical Oral Investigation, 14(3), 257-264.

Molnar-Varlam, C., Molnar-Varlam, C., Gabriela, B., \& Tohati A. (2011). A. Risk assessment of caries in pregnancy Acta Medica Marisiensis, 57(6), 685-689.

Naseem, M., Khurshid, Z., AliKhan, H., Niazi, F., Zohaib, S., \& Sohail Zafar, M. (2016). Oral health challenges in pregnant women: Recommendations for dental care professionals. The Saudi Journal for Dental Research, 7(2), 138-146.

Nisar, N. (2015). Role of mothers in prevention of dental caries: A systematic review. Journal of Dental Health Oral Disorders \& Therapy, 3(3), 269-276.

Núñez, D. P, \& García Ballacao, L. (2010). Bioquímica de la caries dental. Revista Habanera de Ciencias Médicas, 9(2), 156-166.

Oviedo, A., Valladares, M., Napoles, N., Naranjo, M., \& Barreras, B. (2011). The dental caries associated with risk factors during pregnancy. Revista Cubana de Estomatología, 48(2), 104-112.

Peker, I., Mangal, T., Erten, H., Alp, G., Avci, E., \& Akca, G. (2012). Evaluation of caries risk in a young adult population using a computer-based risk assessment model (Cariogram). Journal of Dental Sciences, 7(2), 99-104.

Petti, S., \& Hausen, W. (2000). Caries prediction by multiple salivary mutans streptococcal counts in caries-free children with different levels of fluoride exposure, oral hygiene and sucrose intake. Caries Research, 34(5), 380-387.

Piovano, S., Squasssi, A., \& Bordoni, N. (2010). Estado del arte de indicadores para la medición de caries dental. Journal of the Faculty of Dentistry, 25(58), 29-43.

Reis, D. M., Rocha Pitta, D., Barbosa Ferreira, H. M., Pinto de Jesus, M., Leonelli de Moraes, C., \& Gonçalves Soares, M. (2010). Health education as strategy for the promotion of oral health in the pregnancy period. Ciência e Saúde Coletiva, 15(1), 269-76.

Rodríguez Lezcano, A., León Valle, M., Arada Otero, A., \& Martínez Ramos, M. (2013). Factores de riesgo y enfermedades bucales en gestantes. Revista de Ciencias Médicas de Pinar del Rio, 17(5), 51-63.

Rojas, S., \& Echeverría, L. S. (2014). Caries temprana de infancia: ¿enfermedad infecciosa? Revista Médica Clínica Las Condes, 25(3), 581-587.

Silk, H., Douglass, A. B., Douglass, J. M., \& Silk, L. (2008). Oral health during pregnancy. American Family Physician, 77(8), 1139-44. 
Tellez, M., Gomez, J., Pretty, I., Ellwood, R., \& Ismail, A. (2014). Evidence on existing caries risk assessment systems: Are they predictive of future caries? Community Dentistry and Oral Epidemiology, 1(1), 67-78.

Vargas, C. M., Kramarow, E. A., \& Yellowitz, J. A. (2001). The oral health of older Americans. Centers for disease control and prevention. National Center for Health Statistics. Retrevied from https://www.cdc.gov/nchs/ data/ahcd/agingtrends/03oral.pdf

Villa, A., Abati, S., Pileri, P., Calabrese, S., Capobianco, G., Strohmenger, L, Ottolenghi, L., Cetin, I., \& Campus, G. G. (2013). Oral health and oral diseases in pregnancy: A multicentre survey of Italian postpartum women. Australian Dental Journal, 58(2), 224-9.

Volpato, F. C., Jeremias, F., Spolidório, D. M., Silva, S.bR., Valsecki, J. A., \& Rosell, F. L. (2011). Effects of oral environment stabilization procedures on Streptococcus mutans counts in pregnant women. Brazilian Dental Journal, 22(4), 280-284.

Wagle, M., D’Antonio, F., Reierth, E., Basnet, P., Trovik, T. A., Orsini, G., Acharya, G. (2018). Dental caries and preterm birth: A systematic review and meta-analysis. BMJ open, 8(3), Retrevied from: https://www.ncbi. nlm.nih.gov/pmc/articles/PMC5855295/

WHO Expert Consultation on Public Health Intervention against Early Childhood Caries (2016). Report of a meeting. Retrevied from: https://apps.who.int/iris/bitstream/handle/10665/255627/WHO-NMHPND-17.1-eng.pdf;jsessionid=3865DABEE5290C56FE116493B3A8EA45 ?sequence $=1$

\section{BY-NC-ND}

